\title{
OPTİMUM BESLENMEDE SAĞLIKLI ATIŞTIRMALIKLARIN YERİ
}

\author{
Celalettin Değerli*, Sedef Nehir El \\ Ege Üniversitesi, Mühendislik Fakültesi, Gıda Mühendisliği Bölümü, İzmir, Türkiye
}

Geliş / Received: 26.03.2019; Kabul / Accepted: 22.08.2019; Online bask1 / Published online: 16.10.2019

Değerli, C., El, S.N. (2019). Optimum beslenmede sağlıklı atıştırmalıkların yeri. GIDA (2019) 44 (6): 988999 doi: $10.15237 /$ gida.GD19071

Degerli, C., El, S.N. (2019). Importance of healthy snacks in optimal nutrition. GIDA (2019) 44 (6): $988-999$ doi: 10.15237/gida.GD19071

\section{ÖZ}

Günümüzde beslenmenin genel sağlığın korunmasındaki önemi, medya araçları ile toplumun her kesimine ulaşacak şekilde popüler bir noktaya gelmiştir. Obezite, tip-2 diyabet, damar sertliği (ateroskleroz) gibi kronik rahatsızlıkların oluşumunun engellenmesi, kilo korunumunun sağlanması gibi gerekçeler ile sağlıklı beslenme arayışının bir yönünü de sağıklı atıştırmalıklar oluşturmaktadır. Atıştırmalıklar her toplumun beslenmesinde önemli bir yer tutmaktadır. Fakat gıda endüstrisi tarafından üretilen atıştırmalık reçetelerinin büyük bir kısmı, yüksek enerji ve düşük besin öğesi içerikleri nedeniyle optimum beslenmeye katkıları olmadığı yönünde değerlendirilmektedir. Dolayısıyla üretilmekte olan bu atıştırmalıklarda, reçetelerin yeniden düzenlenmesi bir gereklilik olarak ortaya çıkmışır. Bu derlemede öncelikle optimum beslenme yaklaşımı ve beslenme rehberleri, çocuk ve ergen beslenmesi, sporcu beslenmesi genel hatlarılla anlatılmış ve atışturmalık gıdaların ilgili beslenme şekillerinde yaratmakta olduğu olumsuz etki vurgulanmışır. Daha sonra atıştırma eyleminin tarihi ve atıştırmalık kültürü anlatılmış, ülkemizde ve dünyada satışa sunulan atıştırmalıklar alanında yapılan düzenlemeler ile sağlıklı atıştırmalıklar alanında yapılan akademik çalışmalar incelenmiştir.

Anahtar kelimeler: Atışırmalık, optimum beslenme, beslenme rehberleri, çocuk ve ergen beslenmesi, sporcu beslenmesi

\section{IMPORTANCE OF HEALTHY SNACKS IN OPTIMAL NUTRITION}

\begin{abstract}
Snacks have an important place towards nutrition of every society. However, most recipes of the snacks in the food industry create excessive calorie amount and unbalanced nutrient composition. Recently, importance of nutrition for general protective effects on health such as reducing risk of obesity, type-2 diabetes, atherosclerosis and helping to keep ideal body weight is quite popular to reach every part of the society. Healthy snacks are just another point of healthy nutrition for consumers. In this review, optimum nutrition approach and dietary guidelines, children and adolescence nutrition and sports nutrition expressed in general and the negative effect of snacks on related nutrition types were emphasized, first. After that, the culture of snacking, regulations on snacks and studies on healthy snack development were investigated.

Keywords: Snack, optimum nutrition, dietary guidelines, children and adolescence nutrition, sports nutrition
\end{abstract}

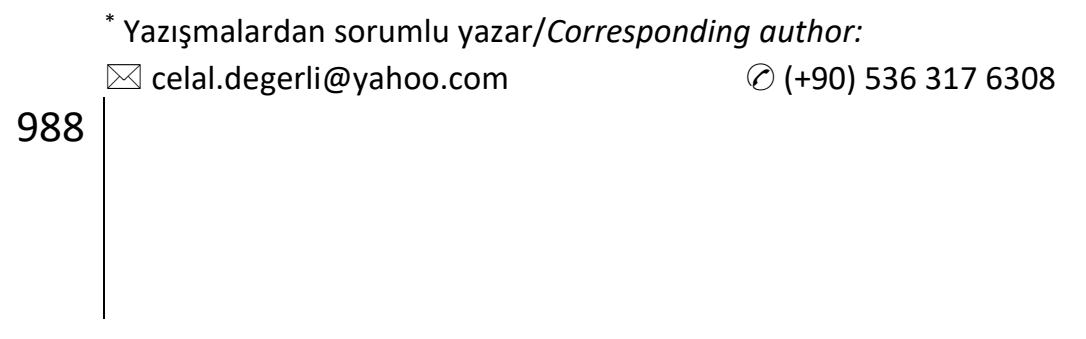




\section{GİRIŞ}

2000'li yıllardan itibaren yapilan bilimsel çalışmaların sonuçlarına göre, beslenme tercihleri ve fiziksel aktivite düzeyi, obezite, tip-2 diyabet, insülin direnci gibi bazı kronik hastalıkların oluşum riski üzerine önemli etkenlerdendir. Dünya Sağlık Örgütü’nün (WHO) 2014 yllı raporunda, Türkiye'deki ölümlerin \%47'sinin kalp-damar hastalıkları ve \%2'sinin diyabet nedeniyle olduğu belirtilmektedir (WHO, 2014). Sağlık Bakanlığı ve WHO'nun hazırladığı başka bir beslenme ve sağllk raporuna göre Türkiye'de yetişkinlerin \%61.9'u fazla kilolu, \%27.8' $i$ ise obezdir (WHO, 2013). Obezitede yalnızca Türkiye'de değil, dünya genelinde de küresel boyutta bir artış söz konusudur. Tüm dünyadaki ölüm nedenlerinin ilk 10 'unun en başında kalpdamar hastalıkları, altınc1 sirada ise Tip 2 diyabet gelmektedir (WHO, 2017).

Amerika Birleşik Devletleri Tarım Bakanlığ1 (USDA) tarafindan ve Birleşmiş Milletler Tarım Örgütü (FAO) ve WHO ortaklığ1 ile hazırlanan beslenme rehberine göre optimum beslenme modelinde gidalar 6 temel gruba ayrilmıştır. Bunlar meyveler, sebzeler, tahillar (hububatlar), protein grubu (et, tavuk, balık, yumurta, baklagiller ve yağlı yemişler), süt ve süt ürünleri ile yağlar olarak belirlenmiştir. Tüketicinin günlük diyetinde her gida grubundan farklı gidalara yer vermesi halinde sağlıklı bir beslenme modeli için ilk basamak tamamlanmış olacaktır. Bununla birlikte, gıdanın sağladığı besin öğesinin yanı sıra sağladığ1 enerji miktarına da dikkat edilerek gıda seçimlerinin yapılması, ilave şeker ve doymuş yağlardan gelen kalori miktarına dikkat edilmesi ve sodyum alımının azaltılmasının önemli yaklaşımlar olduğu belirtilmektedir. Böylelikle sağlıklı vücut ağırlığına erişilebilecek, zihinsel ve fizyolojik sağlık korunabilecek ve yukarıda sözü edilen kronik rahatsızlıklara yakalanma riski azaltılacaktır (USDA, 2015).

Türkiye'de, dünyadaki örnekleri de referans alınarak "Türkiye Beslenme Rehberi-TÜBER" hazırlanmıştır (TÜBER, 2016). Bu rehberde optimum beslenme yaklaşımı doğrultusundaki diyet önerileri dışında; besin öğesi yetersizliklerinin ve gida alerjisine sahip bireylerin yaş gruplarına göre dağllımı gibi özel veriler de bulunmaktadır. Bu rehbere göre, Türkiye'de toplam protein alımının \%58'inin bitkisel gıdalardan sağlandığı görülmektedir. Bu oranın $\% 40$ 'lık bölümü lizin aminoasidi yönünden fakir olan tahillardan; özellikle de rafine tahil ürünlerinden gelmektedir. İstatistiklere göre yetişkin bireylerde kadınların \%45.3'ü, erkeklerin $\% 26.8$ 'i önerilen protein alım miktarını sağlamayan bir diyetle beslenmektedir (TÜBER, 2016). Toplum genelinde çinko yönünden \%44.9, potasyum yönünden ise $\% 96.1$ yetersiz beslenme söz konusudur. Toplam yağ alımı ise, Türkiye genelinde, Günlük Referans Değeri (GRD)'nin \%48 daha fazlasıdır (Sağlık Bakanlığı, 2014).

TÜBER'de değinilen bir diğer önemli konu da okul çăg1 ve ergenlik dönemi (6-18 yaş) beslenmesidir. Bu dönemde Türkiye'de görülen sağlık sorunları şişmanlık, obezite, kalsiyum yetersizliği, D vitamini yetersizliği, iyot yetersizliği, anemi (kansızlık), yeme davranışı bozuklukları ve diş çürükleridir (Sağlık Bakanlı̆̆1, 2014). Türkiye Cumhuriyeti Sağlık Bakanlığ1 ve Milli Eğitim Bakanlığı, bu verilerin doğrultusunda bir düzenleme yaparak 2016 yilinda "Okul Kantinlerinde Satılacak Gıdalar ve Eğitim Kurumlarındaki Gıda İşletmelerinin Hijyen Yönünden Denetlenmesi” konulu bir genelge yayınlamıştır. $\mathrm{Bu}$ genelgede ilköğretim kurumlarında satışı uygun olan ve uygun olmayan gıdalar belirtilmiştir (Milli Eğitim Bakanlığı, 2016). Okul kantinlerinde satışı yasak gıdaların belirlenmesi ile enerji, şeker veya yağ içerikleri oldukça fazla birçok gıda liste dışı kalmıştır. Bununla birlikte, çocukların severek ve ilgi göstererek tercih edebilecekleri, sağlıklı atışıırmalık gıda çeşitlerinin artırılmasıyla ilgili bir gereksinimi de ortaya çıkmışıı.

Atıştırmalıklar aynı zamanda, aktif yaşamın ve spor aktivitelerinin önerildiği bu rehberde, sporcu beslenmesi için de önemli bir noktadadır. Sporcu beslenmesi, yapılan sporun çeşidine, yoğunluğuna, süresine ve sporcunun fiziksel durumuna göre farkl1lık gösterebilen oldukça önemli bir alan olmakla birlikte, beslenmenin, genetik yap1 ve fiziksel kondisyon ile birlikte performans1 etkileyen temel faktörlerden biri 
olduğu kanıtlanmıştır (Ersoy ve Hasbay, 2008). Dikkat edilmesi gereken en önemli konular, sporcunun enerji ve besin öğesi ihtiyacındaki değişimlere göre menü planlaması, egzersiz zamanına göre gida alımının doğru zamanda yapilması ve bununla birlikte sporcunun damak zevkine uygun tercihlerin olmasidır. Ancak, genellikle sporcular ve çalıştırıcılar, optimum performansı sağlayacak diyet uygulamalarından daha ziyade, doğrudan performansta artışa yol açabilecek gidalar ve/veya bileşenler arayışındadırlar. Mevcut çalışmaların ışığında sporcu performansina doğrudan olumlu etki edecek, bilimsel olarak kanıtlanmıs herhangi bir gıda veya bileşen yoktur. Yalnızca ergojenik yardımcilar olarak nitelendirilen kafein, kreatin fosfat, $\beta$-alanin, nitrat ve sodyum bikarbonatin belirli dozlarda, yeterli bir diyet ile birlikte sporcu performansını artırmaya yardımcı olduğuna dair bulgular mevcuttur (Thomas vd., 2016). Sporcunun kalori ve besin öğelerine olan ihtiyac1, tükettiği gıda miktarının da artmasına yol açmaktadır. Gıda miktarındaki bu artış, sporcunun bir ögünde tüketebileceği yaklaşı miktar göz önüne alındığında çoğu zaman 3 ana öğü ile tamamlanamayan bir açık oluşturmaktadır. $\mathrm{Bu}$ açığın kapatılması, ana öğünlerin yanı sıra ara öğünler için duyusal yönden çekici, besleyici ve sağlıklı atışırmalık (katı ve s1v1 formlarda) tasarımlar1 ile mümkün görülmektedir.

Atıştırmalık tasarımları ile diyet ve/veya ara öğün uygulamalarinda ihmal edilen konulardan biri de tüketicinin damak zevkine uygun seçimlerin yapılamamasıdır. Uluslararası bir anket şirketinin 2016 yllında gerçekleştirdiği tüketici anketlerinde Türk tüketicisine atıştırmalıklarda öncelikli tercihleri sorulmuştur. Buna göre tüketicilerin $\% 70$ 'i meyve çeşitlerini, $\% 58$ 'i bisküvi ve $\% 18$ 'i barları atıştırmalık kategorisinde tercih etmişlerdir. Yine, Türk tüketicisinin \%51'i zaman bulamadığ1 için öğün atladığını ve atıştırmalık tükettiğini bildirmiştir. Anket çalışmasının sonucunda, 'şeker ilavesiz', 'lif kaynağı', 'proteince zengin', 'kalorisi azaltılmış', 'düşük sodyumlu' gibi beslenme beyanlarına sahip atışırmalıkları tercih eden, bilinçli bir tüketici grubunun oluştuğu görülmüştür (New Nutrition Business, 2016).
Tarım ve Orman Bakanlığ1 tarafindan, Avrupa Birliği yönetmeliklerine uyum çalışmaları çerçevesinde beslenme ve sağlık beyanları üzerine yapılan düzenlemeler ile 200'den fazla beyanının yapılmasina olanak tanıan bir 'Türk Gida Kodeksi Beslenme ve Sağllk Beyanları Yönetmeliği’ yayınlanmıştır (Resmi Gazete, 2017).

\section{OPTİMUM BESLENME YAKLAŞIMI VE BESLENME REHBERLERİ}

Yaşamın ideal kalitede sürdürülmesi, büyümenin ve gelişmenin eksiksiz sağlanması, zihinsel, fiziksel ve duygusal sağlığın korunması için, gerekli besin öğelerinin ve biyoaktif bileşenlerin tüketilmesi, optimum beslenme yaklaşımının temelidir. Buna göre, yaşamsal faaliyetlerin devamı için enerji, makro besin öğeleri (karbonhidratlar, proteinler ve yağlar) ve mikro besin öğeleri (vitaminler, mineraller) günlük gereksinimi karşılayacak düzeyde alınmalıdır. Buna ilave olarak, sağlık üzerine potansiyel olumlu etkileri bilinen biyoaktif bileşenlerin (peptitler, fitosteroller, antioksidanlar, karotenoidler, fenolik bileşikler, koenzim $\mathrm{Q}_{10}$ gibi) alınması ile ileriki yaşlarda karşılaşılabilecek hastalıkların riskinin azaltılması amaçlanmaktadır (El ve Şimsek, 2012). Optimum beslenmenin toplum geneline yayılabilmesi için çoğu ülkede beslenme rehberleri yayınlanmaktadır. Bu rehberler genellikle 5 temel prensip üzerine hazırlanmaktadır:

-Toplumlar için diyet, gıdaların vücuda alınmasindan daha fazlasını ifade etmekte; aynı zamanda sosyal ve kültürel değerler barındıran bir alışkanlığı da oluşturmaktadır. Bu nedenle diyet önerilerinde, toplum sağllğı öncelikle gözetilecek şekilde, gidaların hangi kombinasyonlarla hazırlanabileceği ve tüketilebileceği; sosyal ve kültürel gıda tercihleriyle harmanlanmalıdır.

-Beslenme önerileri, ülkedeki gıda kaynakları ve genel toplum sağllğındaki değişimlere göre düzenlenmelidir. Örneğin, nüfusun önemli bir paydasında toplam yă alımı yetersizliğ görülmeye başlanmıssa, diyetteki toplam yă̆ miktarını artıracak beslenme önerileri yapılmalıdır. -Sağlıklı beslenme önerileri aynı zamanda sosyal ve çevresel yönden sürdürülebilir nitelikte olmalıdır. Ülkenin beslenme alışkanlıklarına uygun olmasinin yanında, ham madde kaynakları 
ve ekonomik özellikleri de dikkate alınarak, rasyonel nitelikte olmalıdır.

-Yapılacak öneriler farklı kaynaklardan elde edilmiş ve bilimsel olarak kanıtlanmış bilgilerin 1şı̆̆ında olmalıdır.

-Beslenme önerileri toplum genelinde bir refleks yaratmalı; yeterli gıdaya ulaşabilmenin temel haklardan biri olduğu bilincini oluşturmalı ve/veya bu bilinci desteklemelidir (PérezEscamilla, 2016; USDA, 2015; Ministry of Health of Brazil, 2014; Republic of South Africa Department of Health, 2013; TÜBER, 2016 ).

Beslenme rehberlerindeki beslenme önerileri, o ülkeye ait sağllk istatistiklerine ve besin öğesi yetersizliği verilerine göre yapılmaktadır. Türkiye'de diyet lifi yönünden yetersiz beslenenlerin oran1 \%68.2, proteince eksik beslenenlerin oranı \%37.9'dur. Tüketimi artırılması gereken gıdalar günlük taze meyveler ve sebzeler, tam tahıllar, kuru baklagiller, süt ve süt ürünleri, balık ve deniz ürünleridir. Ayrıca D vitamininin Türkiye genelinde tüm yaş gruplarında yetersiz olması dikkat çekmektedir (TÜBER, 2016). Bu yetersizlikler için beslenme önerileri yapılırken alınan gıdanın günlük enerjiyi sağlama oranının, besin öğesini sağlama oranından düşük olmasina (besin öğesi yoğunluğunun yüksek olmasina) dikkat edilmelidir. Ayrıca çeşitliliğin artırılması, porsiyon miktarının azaltılması, ilave şeker ve doymuş yağlardan gelen kalorinin azaltılması, sodyum alımının azaltılması ve bu yaklaşımların ev, işyeri, okul, vb. her yerde uygulanması gerekmektedir (USDA, 2015; TÜBER, 2016).

\section{Okul Çağ1 ve Ergenlik Döneminde Beslenme} Sağlıklı bir yaşam için beslenmenin her yaş grubunu kapsayacak şekilde önemi kanttlanmış olmakla birlikte, okul çağı ve ergenlik döneminde duyusal yönden oldukça çekici olan, toplam kalorisi ve yağ içeriği yüksek, besin öğesi dengesi sağlanmamış ana ve ara öğünlerin ileriki yaşlardaki hastalık risklerini artırıc1 etkisi önemsenmelidir. Öncelikle tüm dünyada olduğu gibi Türkiye'de de çocukların genellikle kahvaltı öğününü atladıkları görülmektedir. Türkiye'de çocukların günlük protein alımı GRD'nin oldukça altındadır. Bu durum, lif, $\mathrm{B}_{12}$ vitamini, magnezyum, iyot ve potasyum için de geçerlidir. D vitamini 6-18 yaş grubunda \%99.1 oranında yetersizdir, yine ülke genelinde çocukların \%73'ü kalsiyum, \%45.7'si çinko, \%48'i demir, \%29.8'i C vitamini ve \%43'ü de $\mathrm{E}$ vitamini yönünden GRD'nin altında beslenmektedir. Ayrıca TÜBER'de çocuk ve ergen beslenmesi için örnek menü planlamaları da yapılmıstır (Sağlık Bakanlığ1, 2014; TÜBER, 2016). Milli Eğitim Bakanllğ1 tarafindan yayımlanan 'Okul Kantinlerinde Satılacak Gidalar' genelgesi ile çocuk ve ergen beslenmesinin önemi vurgulanmıştır (Milli Eğitim Bakanlığ1, 2016). Bu genelgede satışı yasaklanan ve izin verilen yiyecek ve içecekler listelenmiştir ve ambalajlı gıdalar için satışa uygunluk ölçütleri belirtilmiştir (Çizelge 1). Bir başka çalsşma ise 'Beslenme Dostu Okullar Projesi’ çerçevesinde Sağlık Bakanlığı tarafindan yürütülen "Beslenme Dostu Okul Sertifikası" programıdır. Bu projeye dâhil olacak kurumlarda sağlıklı beslenme ve fiziksel aktiviteye yönelik faaliyetler ve düzenlemeler yapılması istenmektedir. Proje ölçütlerini yerine getiren 2237 okul 2016 yll itibariyle "Beslenme Dostu" unvanı almaya hak kazanmıştır (Milli Eğitim Bakanlığı, 2016; Sağlık Bakanlığı, 2016).

\section{Sporcu Beslenmesi}

TÜBER'de sporcu beslenmesi bir başlık altında toplanmış ve makro/mikro besin öğeleri ile yeterli sıv1 alımı önerilerinde bulunulmuştur. Sporcu gereksinimi olan karbonhidratların -çeşitlilik vurgusu yapılarak- tahıllardan, baklagillerden, meyve ve sebzelerden sağlanması gerektiği belirtilmiştir (TÜBER, 2016). Spor yapan bireyin enerji gereksinimini sağlamak, kas glikojeni depolarını dolu ve gerektiğinde harcayacak şekilde hazır tutabilmek için kompleks karbonhidrat alımını artırması gerekmektedir. Glikojen depolar1, sporcunun performansinı belirleyen önemli bir faktördür ve doğru bir diyetle ve egzersiz programiyla bu depolann kapasitesi de artırilabilmektedir. Optimum beslenme yaklaşımında günlük diyette tüketilen karbonhidrat miktarının, alınan enerjinin toplam enerjinin \%50-55'ini sağlaması önerilmektedir. Sporcu beslenmesinde ise bu oranın yoğun egzersiz döneminde veya dayanıklılık sporlarında (maraton, triatlon, bisiklet turlar1 ve yüzme şampiyonaları gibi) \%70'e kadar çıkabilmektedir. 
Vücut geliştirme ve profesyonel düzeydeki dayanıklıl1k sporları haricinde sporcunun protein ihtiyacı genellikle değişmemektedir (günde 0.9-1 g protein/ $\mathrm{kg}$ vücut ağırlığı). Alternatif bir yaklaşım olarak, yapilan spor sonrası GRD'ye ilave olarak $\mathrm{kg}$ vücut ağırlığı başına $0.3 \mathrm{~g}$ protein alımı önerilmektedir. Ancak bu yeni yaklaşımın genel kabul görebilmesi için daha fazla çalışmaya ihtiyaç duyulmaktadır (Carlsohn, 2016; Phillips, 2014; Thomas et al., 2016). Genel olarak sporcu için porsiyon miktarının artırılması, iştah duyulmadığ1 halde yemek zorunda kalınması ve yemek yemenin çekici gelmemesine yol açmaktadır. $\mathrm{Bu}$ nedenle ana öğünlerde tüketilen g1da miktarını artırmak yerine, ara öğün sayısının veya ara ögünlerdeki porsiyon miktarının artırılması tercih edilmektedir (Kreider et al., 2010). Gıda endüstrisi tarafindan gerçekleştirilen anket çalışmaları sonucunda, gida üreticileri sporcu beslenmesine uygun reçetelere sahip, besin öğesi yoğunluğu yüksek atıştırmalıklar geliştirilmektedir. Bu atıstırmalıklar genellikle izotonik içecek, bar, kurabiye, jel ve kek formundadır (Isostar, 2019; Sante, 2019, Powerbar, 2019).

Çizelge 1: Ambalajlı gıdalar için kantinlerde satışa uygunluk ölçütleri (Milli Eğitim Bakanlığı, 2016) Ürün Özelliği

-Ürünün toplam enerji içeriği $200 \mathrm{kkal}$ değerini aşmamalıdır.

-Ürünün yağdan gelen enerjisi toplam enerjinin \%35’ini aşmamalıdır.

-Ürünün doymuş yağdan gelen enerjisi toplam enerjinin \%10’unu aşmamalıdır.

-Doğal ve eklenmiş şekerden gelen enerji toplam enerjinin \%10’unu aşmamalıdır.

-Ürünün sodyum içeriği $200 \mathrm{mg}$ değerini aşmamalıdır.

-Dondurma, sütlü buz, bitkisel yağlı sütlü buz, sütlü tatlllarda ürünün enerjisi ve doymuş yağ içeriği

$150 \mathrm{kkal}$ ve $3 \mathrm{~g}$ değerini aşmamalıdır.

-Yenilebilir buzlu ürünler \%99'dan fazla meyve suyu içermeli, şeker eklenmemiş ve miktarll 125 mL'den az olmalıdır.

-Ezilmiş/kırılmış buzlu içecekler \%99'dan fazla meyve suyu içermeli, şeker eklenmemiş ve miktarlı 200 mL'den az olmalıdır.

-Üretiminde şeker kullanılan, çeşnili ve/veya aroma verici içeren içme sütlerinde; eklenmiş şeker 5 $\mathrm{g} / 100 \mathrm{~mL}$ ve toplam şeker $9,5 \mathrm{~g} / 100 \mathrm{~mL}$ değerlerini aşmamalıdır.

-Üretiminde şeker kullanılan çeşnili ve/veya aroma verici içeren yoğurtlarda; toplam şeker miktarı $12,5 \mathrm{~g} / 100 \mathrm{~g}$ değerini aşmamalıdır

-Meyve ve sebze sular $\% 100$ meyve ve sebze suyu olmal, ilave şeker içermemeli, 250 mL'den büyük olmamalidir.

-Liselerde çay ve kahve tarzı içecekler en fazla $375 \mathrm{~mL}$ olmalıdır.

\section{ATIŞTIRMALIK GIDALAR VE YASAL DÜZENLEMELER}

Atıştırmalık gıdalar yüzyllardır evlerde hazırlanmakta ve yaklaşı yüz yıldır gıda endüstrisi tarafindan üretilmektedir. "Atıştırmak" (snacking), "atıştırmalık" (snack) ve "atı̧stırmalık gıda" (snack food) kelimeleri için kesin bir tanım yapılamamaktadır. Bunun nedenleri tüketici ve atıstırmalık kaynaklı olarak ikiye ayrılmaktadır. Tüketicinin yaş1, cinsiyeti, vücut ağırllğı, başta gelenekler olmak üzere tüketicinin ait olduğu kültürel farkllıklar ve ekonomik durumundaki farklılıklar öne çıkmaktadır. Atıştırmalık gıdanın ise tüketildiği zamanın, porsiyon miktarının, tüketildiği yerin ve tüketim sıklığının kişiden kişiye değişkenlik göstermesi, bu kavramlar için kesin bir tanım yapılabilmesine engel olmaktadır. Yine de çoğu beslenme rehberinde ana öğünler arasında tüketilen yiyecekler ve kalori içeren içeceklerin tamamına, kısaca atıştırma eylemi yapılan her gıdaya "atıştırmalık" adı verilmektedir. "Atıştırmalık gıda" ise bazı rehberlerde yalnızca bir dizi işlem uygulanmış, besin öğesi yönünden zayıf ama enerji değeri yüksek; yani besin öğesi yoğunluğu düşük olan gıdaları kapsamaktadır (Bellisle, 2014; Grunert vd., 2016; Hess vd., 2016; Zizza, 2014). "Atıştırmak" ise kisa sürede tüketilen, kısa süreli tokluk hissi yaratan, sağlıklı bileşenler içeren/içermeyen gıdaları tüketme eylemi olarak tanımlanmaktadır. Çizelge 2'de bazı 
ülkelerde en sık tüketilen atıştırmalıkların genel tüketici atıştırmalık tercihlerindeki yüzdesi verilmiştir (Hess vd., 2016). Atıştırmanın zamanlaması da kültürden kültüre farklık yaratmaktadır: Fransa'da gouter (öğle ve akşam yemeği arasi), Filipinler'de merienda (öğle ve akşam yemeği arası) ve Güney Amerika'nın genelinde almuerzo (kahvaltı ve öğle arası) şeklinde adlandırılmaktadır. Günümüzde özellikle nüfusu yüksek şehirlerde beslenme tercihleri değişkenlik göstermekte ve atıştırmalık gidalara fazla yönelim yaratmaktadır. Tüketiciler, yoğun iş tempolarında zaman kazanmak amacıyla öğün sürelerini kısaltmakta veya atlamaktadır. Ancak endüstriyel olarak üretilen kek, bisküvi, bar, kraker gibi atıştırmalık gıdalarda tuz, ilave şeker içeriği ve enerji değeri yüksektir (United States Department of Agriculture, 2015).

Çizelge 2. Ülkelere göre en çok tüketilen atıştırmalık gıdalar (Hess vd., 2016).

\begin{tabular}{llc}
\hline Atıştırmalık Gıda & Ülke & $\begin{array}{l}\text { Tüm Atıştırmalıklar } \\
\text { Grubundaki Tüketim } \\
\text { Yüzdesi }\end{array}$ \\
\hline $\begin{array}{l}\text { Tuzlu Krakerler } \\
\text { Tatlllar (kurabiye, kek, vs.) }\end{array}$ & ABD ve Kanada & $\% 14,3$ \\
$\begin{array}{l}\text { Sütlü Tatlllar (şekerli yoğurt, sütlaç, } \\
\text { muhallebi, vs.) }\end{array}$ & ABD & $\% 19,6$ \\
$\begin{array}{l}\text { Meyve } \\
\text { Şekerlemeler }\end{array}$ & Meksika ve Brezilya & $\% 50$ \\
\hline
\end{tabular}

Atıştırmalıklar ve tüketici tercihlerini farklı yönlerden inceleyen birçok anket çalışması yapılmıştır. Tüketicilerin beslenme ve atıştırma yönelimlerini belirleyebilmek için 1994 yllında John De Castro tarafindan geliştirilen "The Weekly Food Diary” (Haftalık Gida Günlüğü) sistemi kullanılmaktadır. Bu sistemde çalıșmaya katılan tüketicinin bir hafta boyunca gerçekleştirdiği tüm gida tüketimini zaman, yer, neden, süre, porsiyon miktarı, lezzet ve duygusal durum gibi ölçütlerini de belirterek kaydetmesi istenmektedir (De Castro, 1994). Yirmi bir Avrupa ülkesini kapsayan ve 16486 kişiyle yapılan bir anket çalş̧masında, tüketicilerin günde 2.8 öğün yemek yedikleri ve 1.6 kez atıştırmalık gida tükettikleri sonucu ortaya çıkmıştır (Bellisle, 2014). Başka bir çalışmada günde 1 ana öğünü atlayan ve bunun yerine atıstırmalık tüketen bireylerin, günde 3 ana öğün sıklığında beslenen bireylere göre daha az $\mathrm{B}_{6}$ vitamini, folik asit, kalsiyum, magnezyum, çinko, demir, sodyum, potasyum ve diyet lif aldıkları belirlenmiştir (Kerver vd., 2006). Başka bir çalışmada, birbiri ile aynı miktarda enerji sağlayan (izokalorik) atıştırmalık veya öğün tüketen bireylerin tokluk duygusu karşılaştırılmıştır. Aynı enerji değerine sahip olmalarına rağmen atıştırmalık tüketen bireylerdeki tokluk duygusunun, ögün tüketenlere göre daha kısa süreli olduğu görülmüştür (Capaldi vd., 2006; Hess vd., 2016). Tüketiciyi atıştırma eylemine iten nedenlerin incelendiği anket çalışmaları da mevcuttur. Burada özellikle göze çarpan nedenlerden biri sosyal çevredir. Yemek yemekte olan kişiye eşlik eden ve daha fazla miktarda yiyen birinin, kişiyi de daha fazla yeme eğilimine yönelttiği görülmüştür. Yalnız yemek yiyen biri için de çevredeki uyaranlar; örneğin çevrede bulunan reklam panoları veya cep telefonlarına gelen mesaj reklamları, kişiyi tok hissederken bile yemek yemeye yönlendirebilmektedir. Öte yandan çeşitli kutlama, dügün, vb. etkinliklerde sunulan atıştırmalık seçeneklerinin neredeyse tamamının kontrolsüz miktarlarda şeker, tuz ve/veya yă̆ içeren yüksek kalorili ürünler (cips, kraker, tatlılar, tuzlanmış ve kavrulmuş kuruyemişler, vb.) olması da sosyal çevrenin kişiyi, ihtiyac1 olmadığ miktarlarda atıştırmaya yönelten önemli bir faktör olduğunu doğrulamaktadır. Bir diğer dikkat çekici detay da bilişsel faktörlerdir. Televizyon izleme ve bilgisayarda çalışma gibi eylemler, can sıkıntısı veya bekleyerek geçen zaman, kişiyi atıştırmaya iten faktörler olarak öne çıkmaktadır (Chapman vd., 2014; Oldham-Cooper vd., 2011). 
Atıştırmalık gıdaların üretim yöntemleri başlıca firınlama, kızartma ve ekstrüzyondur. Özellikle kızartılmış ve ekstrüde ürünler yüksek kalori içermekte, besleyicilik yönünden oldukça zayıf kalmaktadır. Beslenme rehberlerinde atışırmalık gıdaların tüketiminin azaltılması ve gerekiyorsa porsiyon miktarının düzenlenmesi vurgulanmaktadır. Genel olarak atıstırmalık önerileri, yemek kültürüne özgü atıştırmalıklar (baklagiller, tropik meyveler, kuru balık, özel peynirler, reçelli ve tereyağlı ekmekler gibi) haricinde, yoğurt ve benzeri süt ürünleri, kuruyemişler, kuru meyveler, taze meyvesebzeler, tam tahıllı peksimetler ve bisküviler ile ilave şeker içermeyen içecekleri kapsamaktadır (Hess vd., 2016). TÜBER'de atıştırmalık gıdaların tüketiminin azaltılması gerektiği kısaca belirtilmiştir. Ayrıca Türkiye'de besin öğesi yetersizliği görülen ve dikkat çekilmesi gereken çocuk beslenmesi, işçi beslenmesi ve sporcu beslenmesi için hazırlanmış başlıkların altında, mutlaka ara öğünlere yer verilmesi gerektiği, bu ara öğünlerde küçük peynirli sandviçler, kuru yemişler, yoğurt veya meyve tüketimi önerilmiştir (TÜBER, 2016).

ABD Tarım Bakanlı̆̆ (USDA) tarafindan yayınlanan ve 2015-2020 y1llarını kapsayacak şekilde düzenlenen beslenme rehberinde, yeni başlatılan 'Smart Snack' (akıllı atıştırmalık; SS) projesinde atıştırmalık gıdalar özelinde okullarda sağllklı beslenme ve beslenme eğitimi hedef alınmıştır. Yayınlanan SS standardında (Çizelge 3), bir atıştırmalığın SS olarak kabul edilmesi için gerekli özellikleri şu şekilde belirtilmiştir:

Çizelge 3. 'Smart snacks'(SS) atıştırmalık standardı ölçütleri (USDA, 2016).

\begin{tabular}{|c|c|c|c|c|}
\hline Toplam Enerji & Sodyum & Toplam Şeker & Toplam Yağ & Doymuş Yağ \\
\hline $\begin{array}{l}\text { Porsiyon }(30 \mathrm{~g}) \\
\leq 200 \mathrm{kkal}\end{array}$ & $\leq 200 \mathrm{mg}$ & $\begin{array}{l}\text { Kütlece } \% 35 ’ i \\
\text { veva daha az1 }\end{array}$ & $\begin{array}{l}\text { Toplam enerjinin } \\
\% 35 \text { 'i veva daha az1 }\end{array}$ & $\begin{array}{l}\text { Toplam enerjinin } \\
\% 10 \text { 'undan az }\end{array}$ \\
\hline
\end{tabular}

-Atıştırmalığın temel bileşeni tam tahıl, meyvesebze, süt ve süt ürünü veya protein içeren bir gida olmalıdır veya \%25'i meyve ve/veya sebzeden oluşan bir gida karışımı olmalıdır.

-Atıştırmalık aynı zamanda Çizelge 3’te belirtilen diğer ölçütleri de sağlamalıdır.

SS standartlarının kullanımının yaygınlaşması için iki uygulama planlanmıştır. Bunlardan birincisi 'Smart Food Planner' adında SS standartlarını sağlayan ürünlerin kabul edildiği ve listelendiği bir veri tabanıdır (Alliance for a Healthier Generations, 2019a). İkinci ise 'Smart Snack Calculator' adıyla geliştirilen SS besin öğesi miktarının hesaplanmasıdır. Bu programda, tüketicinin satın aldığı ürünün veya üreticinin geliştirdiği ürünün kategorisine (atıştırmalık, içecek ve başlangıçlar) göre veri girmesi (porsiyondaki yağ miktarı, sodyum içerrği gibi) istenmektedir. Girilen verilerin hesaplanmasının ardından kişiye ürününün SS ölçütlerini sağladığ1 veya sağlamadığı gerekçeleri ile bildirilmektedir (Alliance for a Healthier Generations, 2019b). Eğitim kurumlarında SS içecekler kategorisine de standartlar getirilmiştir. Buna göre su ve soda tüketimi sınırsızdır. \%100 meyve ve sebze suları, süt ve tatlandırıcı içermeyen meyveli içeceklerin satışı ilkokullarda $250 \mathrm{~mL} /$ porsiyon, ortaokul ve liselerde $350 \mathrm{~mL} /$ porsiyon ile sinırlandırılmıstır (United States Department of Agriculture, 2016).

\section{BESLEYİCİ VE SAĞLIKLI ATIŞTIRMALIK TASARIMLARI}

Besin öğesi yetersizlikleri veya fazlalıkları konusunda yapilabileceklere katkıda bulunmak üzere, ara öğünlerde tüketilen atıştırmalıkların protein, yağ asitleri ve diyet lif yönünden zenginleştirilmesi önemli yaklaşımlar olarak uygulanmaktadır. Bunun yanı sira karotenoidler, resveratrol, koenzim $\mathrm{Q}_{10}$ ve L-karnitin gibi biyoaktif bileşenlerce zenginleştirilmişs atıstırmalıklar üzerine de akademik ve endüstriyel çalışmalar mevcuttur. Bu konuda gıda endüstrisi tarafindan yapılan önemli yaklaşımlardan biri, gıdaların enerjisini azaltırken besin öğelerinin korunmas1 veya besin öğesi içeriğinin artırilmasıdır (El ve Simsek, 2012; Marques, vd., 2016). Yağ ve şeker ikamelerinin kullanılması, diyet liflerince zengin atıştırmalıklar tasarlanması veya mevcut atıştırmalıkların bu bileşenler ile 
zenginleştirilmesi önem kazanmışır. Danimarkalı bir grup araştırmacı "İdeal atıştırmalık nasıl olmah?" sorusundan yola çıkarak, çok disiplinli (gıda teknolojisi, beslenme, psikoloji ve ekonomi) bir anlayışla 'cool snacks' projesini geliştirmiştir. Bu projede 10-16 yaş grubundaki bireylerin atışırımalıklara yaklaşımları incelenmiştir. İlgili anket çalışmalarıyla, öncelikle bireylerin mevcut atıştırma alışkanlıkları incelenmiş, ideal atışırmalıktan beklentileri (lezzet, görünüş, ambalaj, tüketim yeri ve şekli) sorulmuştur. Alınan cevaplara göre ülkedeki besin öğesi eksiklikleri de gözetilerek, modern teknoloji ve dahası ülkenin lojistik şartlanna da uygun olacak şekilde örnek atıştırmalıklar hazırlanmış, bireylerin beğenisine sunulmuştur. Meyve grubundan üzüm (\%23), ekmek grubundan krema-soğanlı (\%39) olan örnekler en yüksek beğeniye sahip olmuştur. Soslar arasında ise en çok beğeniyi karamel (\%70) almıştır. Bu çalışmayla ilgili başka bir detay da örnek atıştırmalıkların karışıma hazır (Do It Yourself, DIY) ve karıştırılmış olarak iki seçenekle sunulmasıdır. Bu yönden bakıldığında da önceden karıştırılmış olarak paketlenen ürünlerin görsel çekiciliğinin azaldığ1 sonucuna ulaşlmıştır (Grunert vd., 2016).

Günümüzde atıştırmalıkların zenginleştirilmesi veya tasarımı ile ilgili yayınlar her geçen yıl artmaktadır. Bu makalenin yazarları tarafindan 2018 yilında tamamlanan bir yüksek lisans tezi çalışmasında, proteince zengin sağlıklı ve besleyici atıştırmalık tasarımları yapılmıştır. Atışıtırmalıklar hazırlanırken Türk Gıda Kodeksi Beslenme ve Sağllk. Beyanlar (Resmi Gazete, 2017) dikkate alınarak hazırlanan bisküvi ve barlar, fonksiyonel bileşenler (keçi kefiri tozu, nohut unu, peynir altı suyu tozu ve inülin) ile zenginleştirilmiştir. Analiz sonuçlarına göre, bar örneklerinde yülksek protein, yükesek lif, orta glisemik yük ve şeker ilavesiz beyanlar1 yapilabilirken; bisküvi örneğinde şeker ilavesiz, düsük glisemik indeks, yüksek protein beyanlar1 yapılabilmektedir (Değerli, 2018). Bu alanda s1k kullanılan ham maddelerden biri peynir altı suyu konsantresidir (PSK) (Aggarwal vd., 2016; Brown vd., 2004; Marques vd., 2016). Aggarwal vd. (2016) bisküvi üretiminde un karışımında \%70’lik PSK ve reçetede tatlandırıcı (polidekstroz ve maltitol) kullanarak son üründeki yağ ve şeker oranını azaltmayı amaçlamıştır. Çalışma sonunda duyusal yönden başarılı ve enerjisi \%15.98 oranında azaltılmış bisküviler üretilmiştir. Bir diğer çalışmada PSK'nın şekersiz kurabiye üretiminde buğday unu ile yer değiştirmesi amaçlanmıstır. Üretimin ardından kütlece \%30 protein içeriğine sahip kurabiyeler, duyusal yönden de başarılı bulunmuş; şeker ilavesiz ve yüksek protein içeriği beyanlarına sahip bir ürün elde edilmiştir (Marques vd., 2016). Proteinle zenginleştirmenin açlık/tokluk ilişkisine etkisinin

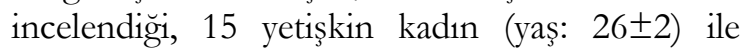
yapılan bir çalışmada 3 farklı protein yüzdesine sahip yoğurt atıştırmalık olarak deneklere sunulmuştur. Deneklerin yoğurdu öğle yemeği ile akşam yemeği arasında belirlenen bir saatte tüketmeleri sağlanmıştır. Ardından 5 saat boyunca 1'er saat arayla deneklere akşam yemeği sunulmuştur. $\% 24$ protein yüzdesine sahip yoğurt tüketen deneklerde, düşük protein içeren yoğurt tüketenlere göre açlık duygusunun belirgin bir şekilde azaldığ1 ve tokluk duygusunun uzadığ1 belirlenmiştir $(\mathrm{p}<0.05)$ (Douglas vd., 2013). Diğer bir çalışmada \%2.6 oranında Spirulina sp. LEB 18 ile zenginleştirilmiş organik misır ve organik pirinç unları karışımından ekstrüde atıştırmalıklar hazırlanmıştır. Analizlerin sonucunda toplam protein, yağ ve mineral miktarlarında kontrol atıştırmalıklarına göre sırasıyla \%22.6, \%28.1 ve \%46.6 oranlarında artış kaydedilmiştir. Kalite yönünden incelendiğinde, sertlik değerlerinde belirgin bir fark kaydedilmeyen ( $p>0.05)$ örnekler aynı zamanda $\% 82$ düzeyinde duyusal kabul almıştır (Lucas, Morais, Santos, Costa, 2018).

Proteince yapılan zenginleştirmelerin dışında diyet lifi ve bazı yağ asitleri ile yapılan ürün geliştirme çalışmaları da mevcuttur. $\mathrm{Bu}$ çalışmalardan birinde inülinle zenginleştirilmiş, maltitol ilaveli ve şekeri azaltılmış yulaflı bisküvi üretilmiştir. Yapılan analizler sonucu bisküvilerin yüksek lif içeriğine ve düşük glisemik indekse (32/100) sahip olduğu tespit edilmiştir (Stamataki vd., 2016). Diyet lif yönünden zenginleştirme denemelerinden biri de çeşitli yöntemlerle ham maddelerin dirençli nişasta (DN) içeriğinin artırılması ya da dışarıdan DN ilavesidir. Dünya genelinde sıkça tüketilen sütlü tatlllardan biri olan pudinglerde yapılan bir çalışmada yüksek amilozlu 
mısır nişastası (YAMN) kullanılarak dirençli nişasta zenginleştirmesi yapılmışıtır (Ares vd., 2009). DN ile yapılan başka bir zenginleştirme çalışmasında granola barlar ve kahvaltılık gevrekler üretilmiştir. Her iki ürün için de sırasıyla DN içermeyen kontrol ve iki farklı oranda (kütlece $\% 10$ ve $\% 15 \mathrm{DN}$ içeriği) zenginleştirme yapılmış örneklerin duyusal ve fizikokimyasal özellikleri incelenmiştir. Her iki örnek de duyusal yönden tüketici kabulü sağlamayı başarmıştır (Aigster vd., 2011). Baklagil unlar1 (mercimek, sar1 bezelye, bezelye, nohut) ve hububat unlar1 (buğday, pirinç, arpa, mısır) karışımları ile hazırlanan ekstrüde atıştırmalıkların nişasta hidrolizi hızına etkisi incelendiği bir çalışmada, zamana bağlı açığa çıkan glukoz miktarları eğrisinin altında kalan alanlar karşılaştırıldığında, baklagil unu ilave edilmiş karışımların daha küçük değerler aldığ1 belirlenmiştir. En büyük düşüşün $(\mathrm{p}>0.05)$ nohut ve buğday unu içeren karışımda hesaplandiğ1 kaydedilmiştir (Patil, Brennan, Mason, Brennan, 2017).

Rogalski vd. (2016) tarafindan yapilan keten tohumu yağı ile zenginleştirme çalışmasında mısır cipslerine $\% 5$ oraninda eklenen keten tohumu, modifiye atmosferde paketlenmiş ambalajlarda 6 ay depolama sonunda, Avrupa Birliği Gida Regülasyonlarında (EU, 2012) öngörülen $2 g \alpha$ linolenik asit / 100g günlük alım miktarını karşılayacak düzeyde bulunmuştur. Bir başka yağ asitleri ile zenginleştirme çalışmasında, sprey kurutucu kullanilarak maltodekstrin ile mikroenkapsüle edilen balık yağ1 (omega-3 yağ asitlerince zengin) karışımları, kurabiye hamuruna eklenerek atıştırmalık gıdaya fonksiyonellik kazandırılması hedeflenmiştir. Çalışmanın sonucunda enkapsülasyonun üründeki lipid oksidasyonunu belirgin bir şekilde azalttığ1 görülmüştür $(\mathrm{P}<0.05)$ Jeyakumari, Janarthanan, Chouksey, Venkateshwarlu, 2016).

Makro besin öğeleri ile zenginleştirme dışında kalan biyoaktif bileşenlerle zenginleştirilmiş atıştırmalıklar da popülerleşen bir alan olarak ortaya çıkmaktadır (Ciudad-Mulero, Barros, Cámara, Morales, Ferreira, 2018; EstebanFernández, Zorraquín-Peña, González de Llano, Bartolomé, Moreno-Arribas, 2017; Martin-Diana vd., 2017). Nar kabuklarıly zenginleştirilmiş kurabiyelerdeki gallik asit, elajik asit ve ellajitanenlerin in vitro biyoerişilebilirlikleri incelendiğinde, kurabiyelerdeki gallik asit biyoerişilebilirliğinin, yalnızca nar kabuklarındaki gallik asit biyoerişilebilirliğine göre $\% 52$ oranında daha fazla olduğu bulunmuştur (Colantuono vd., 2016). Ekstrüde yulaf-misır unu ile yapilan atıştırmalıklara eklenen kurkuminoidin $(750 \mathrm{mg}$ kurkuminoid / $100 \mathrm{~g}$ hamur) ekstrüzyon ve kurutma işlemleri sonrasında önemli düzeyde korunduğu belirlenmiştir (Sayanjali et al., 2019). Yulaf ve fasulye unu ile zenginleştirilmiş kurabiye içeren diyet ile iki ay süresince beslenen diyabetik sıçan deneklerin, kontrol grubuna göre serum glukoz seviyesi, serum trigliserit seviyesi ve serum LDL seviyesinde azalma gözlenmiştir. Araştırmacılar bu etkilerin yulaf ve fasulye ununda bulunan diyet lif, galakto-oligosakkaritler, klorojenik asit, rutin, protokateşik asit, $\beta$ sitosterol ve soyasaponin içeriği ile ilişkili olabileceğini bildirmişlerdir (Iza F Pérez-Ramírez, Laura J Becerril-Ocampo, Rosalía ReynosoCamacho, Mayra D Herrera, 2017).

\section{SONUÇ}

Tüketicilerin bekledikleri duyusal özelliklerden vazgeçmeden sağlıklı beslenme arayışının bir yansıması olan sağlıklı atıştırmalıkların önemi açıkça görülmektedir. Türkiye'de ve dünyadaki beslenme rehberleri incelendiğinde atıştırmalık tüketimi konusuna bazılarında (Meksika, Brezilya, Güney Afrika) detaylıca değinildiği, bazılarında ise henüz ciddi bir etmen olarak dikkate alınmadığ1 (Türkiye, Amerika Birleşik Devletleri, Yunanistan) görülmektedir. Son yıllarda artan ürün geliştirme çalışmaları ile birlikte, yakın gelecekte beslenme rehberlerinde de bu konuya daha fazla yer verileceği tahmin edilmektedir. Özellikle gelecek nesillerde obezite ve diğer kronik rahatsılıkların önlenmesi için çocuk beslenmesinde de önemli bir yeri olan atıştırmalık gıdaların gözden geçirilmesi ve anne-babaların da bu konuda doğru bilgi içeren kanallar (bakanlıklar, kar amac1 gütmeyen kuruluşlar, dernekler ve vakıflar gibi) ile bilinçlendirilmesi gerekmektedir. $\mathrm{Bu}$ alandaki ürün geliştirme çalışmalarının ise devlet ve/veya özel teşviklerle desteklenerek, 
sayıca artırılması ve Türk toplumuna özgü sağlıklı atıştırmalıklar geliştirilmesi beklenmektedir.

\section{KAYNAKLAR}

Aggarwal, D., Sabikhi, L., Sathish Kumar, M. H. (2016). Formulation of reduced-calorie biscuits using artificial sweeteners and fat replacer with dairy-multigrain approach. NFS Journal, 2, 1-7. https://doi.org/10.1016/j.nfs.2015.10.001

Aggarwal, D., Sabikhi, L., Sathish Kumar, M. H., Marques, G. de A., São José, J. F. B. de, Silva, D. A., Sidhu, J. S. (2013). A snack enriched with oral branched-chain amino acids prevents a fall in albumin in patients with liver cirrhosis undergoing chemoembolization for hepatocellular carcinoma. LWT - Food Sci Technol, 43 (2): 1321-1328. https://doi.org/ 10.3109/09637486.2011.596148

Aigster, A., Duncan, S. E., Conforti, F. D., Barbeau, W. E. (2011). Physicochemical properties and sensory attributes of resistant starch-supplemented granola bars and cereals. LWT - Food Sci and Technol, 44(10), 2159-2165. https://doi.org/10.1016/j.lwt.2011.07.018

Alliance for a Healthier Generation. 2019a. "Smart Food Planner" https://foodplanner. healthiergeneration.org/products/ (Erişim tarihi: 28.02.2019).

Alliance for a Healthier Generation. 2019b. "Smart Snacks Product Calculator" https://foodplanner.healthiergeneration.org/calc ulator/ (Erişim tarihi: 28.02.2019)

Ares, G., Baixauli, R., Sanz, T., Varela, P., Salvador, A. (2009). New functional fibre in milk puddings: Effect on sensory properties and consumers' acceptability. LWT - Food Sci Technol, 42(3), 710-716. https://doi.org/10.1016/ j.lwt.2008.10.004

Bellisle, F. (2014). Meals and snacking, diet quality and energy balance. Physiol Behav, 134, 38-43. https://doi.org/10.1016/j.physbeh.2014.03.010

Brown, E. C., DiSilvestro, R. A., Babaknia, A., Devor, S. T. (2004). Soy versus whey protein bars: Effects on exercise training impact on lean body mass and antioxidant status. Nutr J, 3(1), 22. https://doi.org/10.1186/1475-2891-3-22
Capaldi, E. D., Owens, J. Q., Privitera, G. J. (2006). Isocaloric meal and snack foods differentially affect eating behavior. Appetite, 46(2), 117-123. https://doi.org/10.1016/ j.appet.2005.10.008

Carlsohn, A. (2016). Recent Nutritional Guidelines for Endurance Athletes. Dtsch $Z$ Sportmed, 67(1), 7-12. https://doi.org/10.5960/ dzsm.2015.193

Chapman, C. D., Nilsson, V. C., Thune, H. Å., Cedernaes, J., Le Grevès, M., Hogenkamp, P. S., Benedict, C., Schiöth, H. B. (2014). Watching TV and food intake: The role of content. PLOS ONE, 9(7), 7-10. https://doi.org/10.1371/journal. pone.0100602

Ciudad-mulero, M., Barros, L., Cámara, M., Morales, P., Ferreira, I. C. F. R. (2018). Bioactive compounds and antioxidant capacity of extruded snack-type products developed from novel formulations of lentil and nutritional yeast flours. Food Func, 9(2), 819-829. https://doi.org/ $10.1039 / \mathrm{c} 7$ fo01730h

Colantuono, A., Ferracane, R., Vitaglione, P. (2016). In vitro bioaccessibility and functional properties of polyphenols from pomegranate peels and pomegranate peels-enriched cookies. Food Func, 7, 4247-4258. https://doi.org/ $10.1039 /$ c6fo00942e

Değerli, C. (2018). Sporcular için protein bazlı atışırmalık tasarımı. Ege Üniversitesi Fen Bilimleri Enstitüsü Gıda Mühendisliği Anabilim Dalı Yüksek Lisans Tezi, İzmir, Türkiye. 95 s.

European Commission Regulation (EU) No. 432/2012 (2012). http://data.europa.eu/eli/ reg/2012/432/oj (Erişim Tarihi: 05.03.2018)

Douglas, S. M., Ortinau, L. C., Hoertel, H. A., Leidy, H. J. (2013). Low, moderate, or high protein yogurt snacks on appetite control and subsequent eating in healthy women. Appetite, 60(1), 117-122. https://doi.org/10.1016/j.appet. 2012.09.012

El, S. N., Simsek, S. (2012). Food technological applications for optimal nutrition: An overview of opportunities for the food industry. Compr Rev in 
Food Sci Food Saf, 11(1), 2-12. https:// doi.org/10.1111/j.1541-4337.2011.00167.x

Esteban-Fernández, A., Zorraquín-Peña, I., González de Llano, D., Bartolomé, B., MorenoArribas, M. V. (2017). The role of wine and food polyphenols in oral health. Trends Food Sci Technol, 69, 118-130. https://doi.org/10.1016/j.tifs. 2017.09.008

Grunert, K. G., Brock, S., Brunsø, K., Christiansen, T., Edelenbos, M., Kastberg, H., Gunder, S., Krogager, S., Mielby, L. H., Povlsen, K. K. (2016). Cool snacks: A cross-disciplinary approach to healthier snacks for adolescents. Trends Food Sci Technol, 47, 82-92. https://doi.org/10.1016/j.tifs.2015.10.009

Hasbay, A., Ersoy, G. (2008). Sporcu besenmesi. Sağlik Bakanlığı. Klasmat Matbaacilık, Ankara, Türkiye. 28 s. ISBN: 978-975-590-242-5

Hess, J. M., Jonnalagadda, S. S., Slavin, J. L. (2016). What Is a Snack, Why Do We Snack, and How Can We Choose Better Snacks? A Review of the Definitions of Snacking, Motivations to Snack, Contributions to Dietary Intake, and Recommendations for Improvement. Adv Nutr Int Rev J, 7(3), 466-475. https://doi.org/10.3945/ an.115.009571

Isostar. (2019). https://www.isostar.com/wwen/ww-ranges-bars.html (Erişim Tarihi: 01.01.2019)

Iza F Pérez-Ramírez, Laura J Becerril-Ocampo, Rosalía Reynoso-Camacho, Mayra D Herrera, S. H. G.-M. (2017). Cookies elaborated with oat and common bean flours improved serum markers in diabetic rats. J Sci Food Agric, 98(3), 998-1007. https://doi.org/10.1002/jsfa.8548

Jeyakumari, A., Janarthanan, G., Chouksey, M. K., Venkateshwarlu, G. (2016). Effect of fish oil encapsulates incorporation on the physicochemical and sensory properties of cookies. J Food Sci Technol, 53(1), 856-863. https://doi.org/ 10.1007/s13197-015-1981-2

Kerver, J. M., Yang, E. J., Obayashi, S., Bianchi, L., Song, W. O. (2006). Meal and snack patterns are associated with dietary intake of energy and nutrients in US adults. J Am Diet Assoc, 106(1), 4653. https://doi.org/10.1016/j.jada.2005.09.045

Kreider, R. B., Wilborn, C. D., Taylor, L., Campbell, B., Almada, A. L., Collins, R., Cooke, M., Earnest, C.P., Greenwood, M., Kalman, D., Kerksick, C., Klenier, S., Leutholtz, B., Lopez, H., Lowery, L., Mendel, R., Smith, A., Spano, M., Wildman, R., Willoughby, D., Ziegenfuss, T., Antonio, J. (2010). ISSN exercise and sport nutrition review : research and recommendations, $1-43$.

Lucas, B. F., Morais, M. G. de, Santos, T. D., Costa, J. A. V. (2018). Spirulina for snack enrichment: Nutritional, physical and sensory evaluations. LWT - Food Sci and Technol, 90. (2017), 270-276. https://doi.org/10.1016/j.lwt. 2017.12 .032

Marques, G. de A., São José, J. F. B. de, Silva, D. A., Silva, E. M. M. da. (2016). Whey protein as a substitute for wheat in the development of no added sugar cookies. LWT - Food Sci Technol, 67, 118-126. 2015.11.044

Martin-diana, A. N. A. B., Izquierdo, N., Albertos, I., Sanchez, M. S., Herrero, A. N. A., Sanz, M. A., Rico, D. (2017). Valorization of Carob's Germ and Seed Peel as Natural Antioxidant Ingredients in Gluten-Free Crackers. J Food Process Preservation, 41(2). https://doi.org/10.1111/jfpp.12770

Milli Eğitim Bakanlığı. (2016). Okul Kantinlerinde Satılacak Gidalar ve Eğitim Kurumlarndaki Gida İsletmelerinin Hijyen Yönünden Denetlenmesi. Say1: 90757378-10.06-E.2852893

Ministry of Health of Brazil. (2014). Dietary Guidelines for the Brazilian Population. https://doi.org/10.1017/CBO9781107415324.0 04

New Nutrition Business. (2017). 10 key trends in food, nutrition and health 2017. FMCG Gurus consumer surveys 2016.

Oldham-Cooper, R. E., Hardman, C. A., Nicoll, C. E., Rogers, P. J., Brunstrom, J. M. (2011). Playing a computer game during lunch affects fullness, memory for lunch, and later snack intake. Am J Clin Nutr, 93(2), 308-313. https://doi.org/10.3945/ajcn.110.004580 
Patil, S., Brennan, M. A., Mason, S., Brennan, C. S. (2017). Investigation of the combination of legumes and cereals in the development of extrudate snacks and its effect on physicochemical properties and in vitro starch digestion. $J$ Food and Nutr Res, 56(1), 32-41.

Pérez-Escamilla, R. (2016). The Mexican Dietary and Physical Activity Guidelines: Moving Public Nutrition Forward in a Globalized World. J Nutr, 146(9), 1924S-1927S. https://doi.org/10.3945/ jn.115.218784

Phillips, S. M. (2014). A Brief Review of Critical Processes in Exercise-Induced Muscular Hypertrophy, Sport Med, 44, 71-77. https://doi.org/10.1007/s40279-014-0152-3

Powerbar. (2019). https://www.powerbar.eu/ en_GB/products/sport-drink (Erişim Tarihi: 01.01.2019)

Republic of South Africa Department of Health. (2013). Food-Based Dietary Guidelines for South Africa (Vol. 26).

Resmi Gazete. (2017). Türk Gida Kodeksi Beslenme ve Sağllk. Beyanları Yönetmeliği (Vol. 29960).

Rogalski, M., Nowak, K., Fiedor, P., Szterk, A. (2016). Corn Crisps Enriched in Omega-3 Fatty Acids Sensory Characteristic and its Changes During Storage. JAOCS, J J Am Oil Chem Soc, 93(9), 1275-1287. https://doi.org/ 10.1007/s11746-016-2873-y

Sağllk Bakanlığı. (2014). Türkiye Beslenme ve Sağhlk. Arastormast 2010: Beslenme Durumu ve Alşkeanliklarmm Değerlendirilmesi Sonuc Raporu.

Sağlık Bakanlığı. (2019). Beslenme Dostu Okullar Program1. https://okulsagligi.meb.gov.tr/www/ beslenme-dostu-okul-programi-projesi/icerik/16 (Erişim Tarihi: 01.01.2019)

Sante.(2019).

https://www.sante.com.pl/products/c/bars/cer eal-bars/ (Erişim Tarihi: 01.01.2019)

Sayanjali, S., Buckow, R., Gras, S., Ying, D., Sanguansri, L., Augustin, M. A. (2019). Extrusion of a Curcuminoid-Enriched Oat Fiber-CornBased Snack Product. J Food Sci, 84(2), 284-291. https://doi.org/10.1111/1750-3841.14432
Stamataki, N. S., Nikolidaki, E. K., Yanni, A. E., Stoupaki, M., Konstantopoulos, P., Tsigkas, A., Perrea, D., Tentolouris, N., Karathanos, V. T. (2016). Function Evaluation of a high nutritional quality snack based on oat flakes and inulin: effects on postprandial glucose, insulin and ghrelin responses of healthy subjects, 3295-3303. https://doi.org/10.1039/c6fo00559d

Thomas, D. T., Erdman, K. A., Burke, L. M. (2016). Position of the Academy of Nutrition and Dietetics, Dietitians of Canada, and the American College of Sports Medicine: Nutrition and Athletic Performance. J Acad Nutr Diet, 116(3), 501-528. https://doi.org/10.1016/j.jand. 2015.12.006

TÜBER. (2016). Türkiye'ye Özgü Beslenme Rebberi. Sağlık Bakanlığı. http://beslenme.gov.tr/ content/files/arastirmalar/tbsa/1_haziran_t_ber _rehber_y_ksek_kalite.pdf (Erişim tarihi: 01.01.2019)

United States Department of Agriculture. (2015). 2015 - 2020 Dietary Guidelines for Americans (8th edition). https://doi.org/10.1097/ NT.0b013e31826c50af

United States Department of Agriculture. (2016). A Guide to Smart Snacks in School. https://www.fns.usda.gov/sites/default/files/tn /USDASmartSnacks.pdf (Erişim Tarihi: 02.03.2018)

World Health Organization. (2017). Ten years in public health. Ten years in public health, 20072017. Lisans: CC BY-NC-SA 3.0 IGO.

World Health Organization. (2013). Nutrition, Physical Activity and Obesity-Turkey. http://www.euro.who.int/en/nutrition-countryprofiles. (Erişim Tarihi: 03.07.2018)

World Health Organization (WHO). (2014). Non communicable Diseases Country Profiles. Genève : WHO Press, 2014., 1-210. https://doi.org/ $10.1111 /$ jgs.12171

Zizza, C. A. (2014). Healthy snacking recommendations: one size does not fit all. Physiol Behav, 134, 32-37. https://doi.org/10.1016/ j.physbeh.2014.01.034 